\title{
BAD MOUTH
}




\section{ABOUT \\ QUANTUM BOOKS}

QUANTUM, THE UNIT OF EMITTED ENERGY. A QUANTUM BOOK IS A SHORT STUDY DISTINCTIVE FOR THE AUTHOR'S ABILITY TO OFFER A RICHNESS OF DETAIL AND INSIGHT WITHIN ABOUT ONE HUNDRED PAGES OF PRINT. SHORT ENOUGH TO BE READ IN AN EVENING AND SIGNIFICANT ENOUGH TO BE A BOOK. 


\section{Robert M. Adams}

\section{BAD MOUTH \\ Fugitive Papers on the Dark Side}

University of California Press

Berkeley - Los Angeles - London 
University of California Press Berkeley and Los Angeles, California

University of California Press, Ltd.

London, England

Copyright (C) 1977 by The Regents of the University of California

ISBN 0-520-03381-7

Library of Congress Catalog Card Number: 76-50241

Printed in the United States of America

$\begin{array}{llllllll}2 & 3 & 4 & 5 & 6 & 7 & 8 & 9\end{array}$ 
Language was given to man

to conceal his thoughts.

SAINT REAL, TALLEYRAND, OR STENDHAL

Ideas were given to man

to prevent him from thinking.

the PSEUDO-TERTULLIAN 
